\title{
Antinuclear antibodies in systemic sclerosis associated with increased risk of malignancy
}

\section{Przeciwciała przeciwjądrowe w twardzinie układowej związane ze zwiększonym ryzykiem wystąpienia chorób nowotworowych}

\author{
Anna Stochmal, Marta Sar-Pomian, Joanna Czuwara, Lidia Rudnicka \\ Department of Dermatology, Medical University of Warsaw, Poland \\ Katedra i Klinika Dermatologiczna Warszawskiego Uniwersytetu Medycznego, Polska
}

Dermatol Rev/Przegl Dermatol 2018, 105, 604-612

DOI: https://doi.org/l0.5 | /4/dr.2018.79|72

\author{
CORRESPONDING AUTHOR/ \\ ADRES DO KORESPONDENCJI: \\ prof. dr hab. n. med. \\ Lidia Rudnicka \\ Katedra i Klinika Dermatologiczna \\ Warszawski Uniwersytet \\ Medyczny \\ ul. Koszykowa 82 A \\ 02-008 Warszawa \\ e-mail: lidiarudnicka@gmail.com
}

\begin{abstract}
Patients with systemic sclerosis are at 1.5-5-fold increased risk of developing malignant diseases. It has been shown that some types of antinuclear antibodies associated with systemic sclerosis may have predictive value for development of malignant diseases in patients with systemic sclerosis. Patients with circulating anti-RNA polymerase III antibodies (RNAP) are at significantly increased risk of developing a malignant disease (breast cancer, followed by leukemias and gastrointestinal or gynecologic cancers) within 36 months from the onset of the disease $(\mathrm{OR}=7.38)$. Thus, regular cancer screening is recommended in anti-RNAP III-positive patients. An increased prevalence of lung cancer was reported in patients with circulating anti-topoisomerase I antibodies (11.4\%) compared to the median of $2.4 \%$ in all patients with systemic sclerosis. Among patients with circulating anti-centromere antibodies, individuals who are anti-CENP-F-positive are at increased risk of developing breast cancer or lung cancer. Anti-PM-Scl antibodies and anti-Ku antibodies are rare in systemic sclerosis, but may have some association with increased risk of malignancy in these patients as well. Thus, recent data indicate that in patients with systemic sclerosis, diverse disease-specific antinuclear antibodies may be associated with increased risk of developing malignant tumors and require especially careful preventive cancer screening.
\end{abstract}

\section{STRESZCZENIE}

U pacjentów z twardziną układową stwierdza się 1,5-5-krotnie podwyższone ryzyko zachorowania na choroby nowotworowe. Wykazano, że niektóre typy przeciwciał przeciwjądrowych związanych $\mathrm{z}$ twardziną układową mogą mieć wartość predykcyjną dla rozwoju chorób nowotworowych. U pacjentów z krążącymi przeciwciałami przeciw polimerazie III RNA (RNAP III) występuje znacznie zwiększone ryzyko rozwoju choroby nowotworowej (raka sutka, a także białaczek, nowotworów przewodu pokarmowego lub ginekologicznych) w czasie 36 miesięcy od rozpoznania twardziny układowej $(\mathrm{OR}=7,38)$. W związku z tym u wszystkich pacjentów z krążącymi przeciwciałami anty-RNAP III zaleca się regularne badania przesiewowe w kierunku nowotworów. U pacjentów z krążącymi przeciwciałami przeciw topoizomerazie I stwierdzono zwiększoną częstość występowania raka płuca - 11,4\% w porównaniu 
z medianą 2,4\% u wszystkich pacjentów z twardziną układową. Wśród pacjentów z krążącymi przeciwciałami antycentromerowymi i z obecnymi przeciwciałami anty-CENP-F stwierdza się podwyższone ryzyko zachorowania na raka sutka lub raka płuc. Przeciwciała anty-PM-Scl i anty-Ku rzadko towarzyszą twardzinie układowej, ale mogą również wiązać się ze zwiększonym ryzykiem rozwoju nowotworu. U pacjentów z twardziną układową niektóre rodzaje przeciwciał przeciwjądrowych mogą być związane $\mathrm{z}$ podwyższonym ryzykiem wystąpienia nowotworów złośliwych. Pacjenci z tej grupy wymagają regularnych profilaktycznych badań przesiewowych w kierunku nowotworów złośliwych.

Key words: systemic sclerosis, malignancy, cancer, antinuclear antibodies.

Słowa kluczowe: twardzina układowa, nowotwór, rak, przeciwciała przeciwjądrowe.

\section{INTRODUCTION}

Systemic sclerosis (SSc) is a chronic autoimmune disease characterized by thickening of the skin and fibrosis of internal organs and impaired microcirculation [1]. Increased risk of developing a malignancy in patients with SSc has been reported.

The main hallmark of immune dysregulation is the presence of antinuclear antibodies (ANA), which are detectable in $90-95 \%$ of patients with SSc [2]. Antinuclear antibody testing is useful for screening, diagnosis and follow-up of patients with SSc [3, 4]. Moreover, it was demonstrated that particular antinuclear antibodies detected in the serum of patients with SSc may indicate an increased risk of development of malignancy [5]. These include antibodies against RNA polymerase enzymes (anti-RNA polymerase III), topoisomerase I (anti-TOPO/ anti-Scl-70), kinetochore proteins (anti-centromere - ACA), nucleolar antigens (anti-PM/Scl) and proteins involved in DNA repair (anti-Ku) [6]. Furthermore, it was shown that ANAs are present not only in autoimmune diseases but also in the serum of patients with different types of cancers [7]. That suggests a potential association of malignancies with triggering autoimmunity.

The aim of this review is to summarize current data related to the link between antinuclear antibodies in SSc and malignancies.

\section{SYSTEMIC SCLEROSIS AND MALIGNANT DISEASES}

Malignant diseases are observed in 3.9-20.4\% of patients diagnosed with SSc. However, there have been various prevalence ratios reported to date, which may be associated with genetic or en-

\section{WPROWADZENIE}

Twardzina układowa (systemic sclerosis - SSc) jest przewlekłą chorobą o podłożu autoimmunologicznym, która charakteryzuje się stwardnieniem skóry i zwłóknieniem narządów wewnętrznych oraz upośledzeniem mikrokrążenia. U pacjentów z SSc stwierdza się zwiększone ryzyko występowania nowotworów [1].

Głównym wyznacznikiem dysregulacji immunologicznej jest obecność przeciwciał przeciwjądrowych (antinuclear antibodies - ANA), które wykrywa się u 9095\% pacjentów z SSc [2]. Badania ANA są przydatne $\mathrm{w}$ badaniach przesiewowych, diagnostyce i obserwacji pacjentów z SSc $[3,4]$. Stwierdzono ponadto, że określone przeciwciała przeciwjądrowe wykrywane w surowicy pacjentów z SSc mogą wskazywać na zwiększone ryzyko rozwoju nowotworu [5]. Należą do nich przeciwciała przeciw polimerazie III RNA (RNAP), topoizomerazie I (anty-TOPO/anty-Scl-70), białkom kinetochorowym (przeciwciała antycentromerowe ACA), antygenom jąderkowym (anty-PM/Scl) i białkom uczestniczącym w naprawie DNA (anty-Ku) [6]. Stwierdzono również, że ANA występują nie tylko w chorobach autoimmunologicznych, lecz także w surowicy pacjentów z różnymi rodzajami nowotworów [7]. Może to sugerować potencjalny związek nowotworów $\mathrm{z}$ indukowaniem autoimmunizacji.

Celem pracy jest podsumowanie aktualnych danych dotyczących zależności między przeciwciałami przeciwjądrowymi w SSc i chorobami nowotworowymi.

\section{TWARDZINA UKŁADOWA A CHOROBY NOWOTWOROWE}

Choroby nowotworowe występują u 3,9-20,4\% pacjentów z SSc. W piśmiennictwie podawane są 
Table I. Prevalence of malignancies in patients with systemic sclerosis

Tabela I. Częstość występowania nowotworów u pacjentów z twardziną układową

\begin{tabular}{lcccc} 
Author/Autor & Country/Populacja & $\begin{array}{c}\text { Cancer prevalence } \\
\text { in patients with SSc/ } \\
\text { Występowanie } \\
\text { nowotworów } \\
\text { u pacjentów z SSc (\%) }\end{array}$ & $\begin{array}{c}\text { Number of patients with } \\
\text { SSc with the diagnosis of } \\
\text { cancer/Liczba chorych } \\
\text { na SSc z rozpoznanym } \\
\text { nowotworem }\end{array}$ & $\begin{array}{c}\text { Overall number } \\
\text { of patients with } \\
\text { SSc/Ogólna liczba } \\
\text { pacjentów z SSc }\end{array}$ \\
\hline Kuo et al. [49] & Taiwan/Tajwan & 3.9 & 83 & 2053 \\
\hline Sargin et al. [9] & Turkey/Turcja & 4.5 & 7 & 153 \\
\hline Roumm et al. [50] & USA/USA & 5 & 14 & 262 \\
\hline Hashimoto et al. [5।] & Japan/Japonia & 6.7 & 27 & 405 \\
\hline Abu-Shakra et al. [I I] & Canada/Kanada & 7.3 & 90 & 248 \\
\hline Derk et al. [52] & USA/USA & 11.7 & 90 & 469 \\
\hline Hill et al. [53] & Australia/Australia & 20.4 & & 441 \\
\hline
\end{tabular}

vironmental factors (table 1). In total, a 1.5-5-fold higher risk of malignant diseases among SSc patients was estimated [8]. The malignancies occur before, together, or after the diagnosis of SSc [9]. While in rheumatoid arthritis and systemic lupus erythematosus B-cell lymphomas are the most common cancers, in SSc solid tumors of organs affected by fibrosis, such as lungs, esophagus and skin, are more frequently observed $[10,11]$. It was suggested that apart from a genetic predisposition for cancer, inflammatory damage to these organs may trigger their malignant transformation [12] Among solid malignancies, lung cancer was the most common type of cancer in most studies [13]. However, several different types of malignancies were reported among patients with SSc [14].

Significant differences in cancer incidence between diffuse (dcSSc) and limited cutaneous SSc (lcSSc) have been reported. It was shown that overall cancer risk is linked with the dcSSc subgroup, except for breast cancer associated with lcSSc [11, $13,15]$. Furthermore, the prevalence of malignancies in SSc may be increased due to older age at the time of SSc diagnosis and immunosuppressive treatment $[11,16,17]$. The increased incidence of lymphoproliferative and myeloproliferative neoplasms in patients with SSc was related to chronic B-cell stimulation and their malignant transformation [14]. Beside these relatively widely known cancer risk factors, particular antinuclear antibodies specific for SSc have been linked to an increased prevalence of malignancies.

\section{Anti-RNA polymerase III antibodies (RNAP III)}

Anti-RNA polymerase III antibodies may be detected in $9 \%$ of patients with SSc [18]. The presence of these antibodies is associated with rapidly progressive diffuse cutaneous involvement and a higher risk of renal crisis [19]. In recent years the associa- różne dane dotyczące częstości występowania nowotworów, które mogą być związane z czynnikami genetycznymi lub środowiskowymi (tab. 1). Oszacowano, że ryzyko zachorowania na choroby nowotworowe u pacjentów z SSc jest 1,5-5-krotnie wyższe niż w populacji ogólnej [8]. Nowotwory stwierdzane są przed rozpoznaniem, jednocześnie lub po rozpoznaniu SSc [9]. W reumatoidalnym zapaleniu stawów i toczniu rumieniowatym układowym najbardziej powszechnymi nowotworami są chłoniaki z komórek B, natomiast w SSc częściej obserwuje się guzy lite narządów, w których stwierdza się włóknienie w przebiegu choroby, m.in. płuc, przełyku i skóry [10, 11]. Według jednej z hipotez poza predyspozycjami genetycznymi do rozwoju nowotworów przemianę złośliwą mogą również wywoływać uszkodzenia zapalne tych narządów [12]. Wśród nowotworów litych w większości badań najczęstszym typem raka był rak płuc [13], choć u pacjentów z SSc odnotowywano kilka różnych typów nowotworów [14].

Istotne różnice pod względem zapadalności na choroby nowotworowe stwierdzono pomiędzy twardziną układową z uogólnionymi stwardnieniami (diffuse cutaneous SSc - dcSSc) i twardziną układową z ograniczonymi stwardnieniami (limited cutaneous SSc-1cSSc). Wykazano dodatnią korelację między całkowitym ryzykiem zachorowania na raka i dcSSc, w przypadku raka piersi stwierdzono związek z lcSSc [11, 13, 15]. Częstość występowania nowotworów w SSc może być również zwiększona ze względu na zaawansowany wiek pacjenta oraz leczenie immunosupresyjne [11, 16, 17]. Zwiększoną częstość występowania nowotworów limfoproliferacyjnych i mieloproliferacyjnych u pacjentów z SSc wiązano z przewlekłą stymulacją limfocytów B i ich transformacją nowotworową [14]. Wskazuje się również na zależność między zwiększoną częstością występowania nowotworów i obecnością określonych przeciwciał przeciwjądrowych swoistych dla SSc. 
tion between this particular type of antibodies and malignancy has been highlighted. Several studies have confirmed the relationship between malignancies synchronous with SSc onset and positivity for anti-RNAP III antibodies [20-22]. The prevalence of malignancy was reported to be significantly higher in patients with anti-RNA polymerase III antibodies $(31.8 \%)$ than in those with anti-centromere antibodies (5.8\%) and in those with anti-topoisomerase I antibodies (2.4\%) [22]. Moreover, it was demonstrated that there is a close temporal relationship between cancer diagnosis and the development of SSc - a significantly increased risk of developing a malignancy was observed within 36 months from the onset of the disease $(\mathrm{OR}=7.38)$ [23]. The most common malignancy reported in those patients was breast cancer, followed by leukemias and gastrointestinal and gynecological tumors [23]. Due to the fact that anti-RNAP III antibodies are considered as an independent marker of coincident cancer in patients with SSc regardless of age at the diagnosis of SSc, the European League Against Rheumatism Scleroderma Trials and Research group (EUSTAR) recommends regular screening for cancer in anti-RNAP III positive patients $[17,23]$. Some data indicated that the prevalence of malignancies is similar in patients with SSc and antiRNAP III, ACA or anti-TOPO I, but the disease duration at oncologic diagnosis is the shortest in the case of RNAP III antibodies [24]. It was suggested that the temporal relationship between malignancies and antiRNAP III positive SSc may indicate that SSc with this particular type of antibodies may be considered as a paraneoplastic syndrome [25]. Tumors associated with RNAP III positive SSc have been shown to harbor mutated forms of RNA polymerase III autoantigen [25]. Malignancy has been hypothesized to act as a trigger of autoimmunity due to mechanisms involving antitumor immunity, molecular mimicry and epitope spreading $[26,27]$.

\section{Anti-topoisomerase I antibodies (anti-TOPO I)}

Anti-topoisomerase I antibodies (anti-TOPO I) may be detected in $9.4-71 \%$ of patients with SSc and are highly specific for SSc [28]. The antigen for these antibodies is a $70 \mathrm{kDa}$ enzyme involved in DNA replication [29]. Diffuse cutaneous SSc, severe lung and myocardial fibrosis, and renal crisis are characteristic features of patients with anti-TOPO I [30]. Several studies have suggested an increased risk of cancer in patients with SSc and anti-TOPO I positive antibodies. A higher prevalence of lung cancer was reported among patients with SSc and anti-TOPO I antibodies $(11.4 \%)$ compared to a median of $2.4 \%$ in all patients with SSc. The overall increased risk of developing lung cancer in patients with these antibodies was re-

\section{Przeciwciała przeciw polimerazie III RNA (RNAP III)}

Przeciwciała RNAP III wykrywa się u 9\% pacjentów z SSc [18]. Ich obecność wiąże się z szybko postępującym uogólnionym zajęciem skóry i zwiększonym ryzykiem wystąpienia przełomu nerkowego [19]. W ostatnich latach odnotowuje się zależność między występowaniem tego szczególnego typu przeciwciał i rozwojem nowotworów. Kilka badań potwierdziło związek między obecnością nowotworu oraz obecnością przeciwciał anty-RNAP III [20-22]. Stwierdzono, że częstość występowania nowotworów jest istotnie wyższa u pacjentów z przeciwciałami przeciw polimerazie III RNA (31,8\%) niż u pacjentów z przeciwciałami antycentromerowymi $(5,8 \%)$ oraz z przeciwciałami przeciw topoizomerazie I (2,4\%) [22]. Wykazano również, że istnieje ścisły związek czasowy między rozpoznaniem nowotworu i rozwojem SSc - istotnie podwyższone ryzyko zachorowania na nowotwór stwierdzono w czasie 36 miesięcy od wystąpienia choroby $(\mathrm{OR}=7,38)$ [23]. Najczęstszym typem nowotworu stwierdzanym $u$ pacjentów z przeciwciałami RNAP III był rak sutka. Często występowały również białaczki, nowotwory przewodu pokarmowego i ginekologiczne [23]. Ze względu na to, że przeciwciała anty-RNAP III są uznawane za niezależny marker współistnienia nowotworów u pacjentów z SSc, niezależnie od wieku w chwili rozpoznania SSc, European Scleroderma Trials and Research group (EUSTAR) zaleca regularne badania przesiewowe $\mathrm{w}$ kierunku nowotworów u pacjentów z przeciwciałami RNAP III [17, 23]. Niektóre dane wskazują, że częstość występowania chorób nowotworowych u pacjentów z przeciwciałami anty-RNAP III, ACA lub anty-TOPO I jest podobna, jednak czas trwania choroby przy rozpoznaniu onkologicznym był najkrótszy u pacjentów z anty-RNAP III [24]. Zasugerowano też, że ze względu na zależność czasową między rozwojem nowotworu i SSc z obecnością przeciwciał przeciw polimerazie III RNA twardzina układowa $\mathrm{z}$ tym rodzajem przeciwciał może być uznana za zespół paraneoplastyczny [25]. Wykazano, że nowotwory związane z SSc z anty-RNAP III zawierają zmutowane formy autoantygenu polimerazy III RNA [25]. Wysunięto także hipotezę, według której nowotwór działa jak czynnik wyzwalający autoimmunizację ze względu na mechanizmy związane $\mathrm{z}$ odpornością przeciwnowotworową, mimikrą molekularną i rozprzestrzenianiem się epitopów [26, 27].

\section{Przeciwciała przeciw topoizomerazie I (anty-TOPO I)}

Przeciwciała przeciw topoizomerazie I wykrywa się u 9,4-71\% pacjentów z SSc i wykazują one wysoką swoistość dla SSc [28]. Antygenem dla tych przeciwciał jest enzym o masie $70 \mathrm{kDa}$, który bierze udział w replikacji DNA [29]. Charakterystyczne dla pacjentów 
ported as 6.4 [31]. The increased prevalence of lung cancer among patients with SSc and anti-TOPO I antibodies may be explained by the predominant involvement of lungs including extensive fibrosis and chronic inflammation in the affected organ $[12,32]$.

\section{Anti-centromere antibodies (ACA)}

Anti-centromere antibodies (ACA) are directed against proteins essential for the organization of chromosomes during metaphase. Several CENP-A to $G$ antigens were identified as targets of antibodies [33]. CENP-F antigens appear to be highly expressed in malignant tissues. Neoplasms were found in 22 out of 36 patients with anti-CENP-F antibodies. Among these neoplasms breast $(9 / 22)$ and lung (5/22) cancers were most commonly diagnosed [34]. Moreover, it was reported in a Japanese population-based study that positivity for ACA is a statistically significant risk factor for cancers [35]. In particular, breast cancer in SSc patients was associated with ACA positivity and limited cutaneous skin involvement [15] A short time interval between SSc onset and breast cancer diagnosis is highly suggestive of a pathophysiological link, and it appears that SSc, especially with ACA antibodies, may facilitate the development of breast cancer [36].

\section{Anti-PM-Scl antibodies}

Anti-PM-Scl antibodies are directed against complexes of nucleolar proteins with ribonuclease activity which are a part of exosomes involved in RNA processing [37]. Exosomes are considered as cell structures having a remarkable role in the development of neoplasms; they are linked with triggering transformation of healthy cells into malignant cells and promoting proliferation and metastasis of tumor cells [38]. It was reported that some exosome antigens are overexpressed in malignant cells and differ from those found in healthy cells, which may result in breaking the immune tolerance due to uncovering usually hidden epitopes with subsequent recognition of them as immunogenic antigens [39]. Anti-PM-Scl antibodies are present in $2 \%$ of patients with SSc, but are especially commonly found in the sera of patients with myositis overlap (25\%) and other connective tissue diseases [40]. Anti-PM-Scl antibodies were previously reported among patients with dermatomyositis, polymyositis and systemic lupus erythematosus diagnosed with malignancy [41, 42]. However, it has recently been reported that these antibodies seem to be associated with a higher incidence of cancer in SSc as well. The risk of malignancy was estimated as 3.9 times higher for PM-Scl-positive individuals than in SSc patients without this type of antibodies [43]. z SSc z przeciwciałami anty-TOPO I są rozległe zwłóknienia skóry, zwłóknienia płuc i mięśnia sercowego oraz możliwość rozwoju przełomu nerkowego [30]. W kilku badaniach odnotowano zwiększone ryzyko zachorowania na nowotwory złośliwe u pacjentów z SSc i przeciwciałami anty-TOPO I. Częstsze występowanie raka płuca stwierdzono u pacjentów z SSc i przeciwciałami anty-TOPO I $(11,4 \%)$ w porównaniu z medianą (2,4\%) u wszystkich pacjentów z SSc. Całkowity wzrost ryzyka rozwoju raka płuca u pacjentów z tymi przeciwciałami oszacowano na 6,4 [31]. Zwiększoną częstość występowania raka płuc u pacjentów z SSc i przeciwciałami anty-TOPO I można wytłumaczyć uogólnionym rozległym włóknieniem płuc oraz przewlekłym stanem zapalnym w zajętym narządzie [12, 32].

\section{Przeciwciała antycentromerowe (ACA)}

Przeciwciała antycentromerowe (ACA) są skierowane przeciw białkom niezbędnym przy organizacji chromosomów w metafazie. Jako cele przeciwciał zidentyfikowano kilka antygenów: CENP-A do G [33]. Wydaje się, że antygeny CENP-F wykazują wysoki poziom ekspresji w tkankach nowotworowych. W jednym z badań nowotwory stwierdzono u 22 spośród 36 pacjentów z przeciwciałami anty-CENP-F. Najczęściej rozpoznawano rak sutka $(9 / 22)$ oraz rak płuc (5/22) [34]. W badaniu przeprowadzonym w populacji japońskiej wykazano również, że ACA stanowią statystycznie istotny czynnik ryzyka wystąpienia nowotworów [35]. Szczególnie wyraźną dodatnią korelację zaobserwowano między rakiem sutka i obecnością przeciwciał ACA oraz ograniczonym zajęciem skóry [15]. Krótki czas między wystąpieniem SSc a rozpoznaniem raka sutka zdecydowanie wskazuje na obecność zależności patofizjologicznej. Wydaje się, że SSc, zwłaszcza u osób z ACA, może sprzyjać rozwojowi tego typu nowotworu [36].

\section{Przeciwciała anty-PM-Scl}

Przeciwciała anty-PM-Scl są skierowane przeciw kompleksom białek jąderkowych o aktywności rybonukleazy, które stanowią część egzosomów uczestniczących w procesie przetwarzania RNA [37]. Egzosomy są strukturami komórkowymi, które odgrywają niezwykle istotną rolę w rozwoju nowotworów; wiążą się z indukowaniem przemiany zdrowych komórek w nowotworowe oraz pobudzaniem proliferacji i przerzutowania komórek nowotworowych [38]. Stwierdzono, że niektóre antygeny egzosomów ulegają nadekspresji w komórkach nowotworowych i różnią się od tych występujących w komórkach zdrowych. Może to powodować przełamanie tolerancji immunologicznej wskutek ujawnienia zazwyczaj ukrytych epitopów oraz ich późniejszego rozpoznania jako antygenów immunogennych [39]. Przeciwciała anty-PM-Scl są obec- 


\section{Anti-Ku antibodies}

Antibodies against $\mathrm{Ku}$ antigen, which is a protein involved in DNA repair, were primarily associated with systemic lupus erythematosus overlap [44]. Anti$\mathrm{Ku}$ antibodies may also be detected in $2 \%$ of patients with SSc [45]. Myositis and arthritis combined with interstitial lung disease are the most prominent features of patients with this type of antibodies [46]. Moreover, it was found that individuals with anti$\mathrm{Ku}$ are more likely to have a history of malignancy at the time of SSc diagnosis compared with antiKu-negative patients ( $27 \%$ vs. $8 \%$ ) [47]. The overall increased risk was calculated as 4.6-fold higher in anti-Ku-positive patients. The most commonly reported malignancies were melanoma, breast cancer and squamous cell skin cancer [47]. The link between anti-Ku antibodies and cancers might be explained by triggering autoimmunity via genetic alterations of the $\mathrm{Ku}$ antigen and molecular mimicry. Alternatively, overexpression of repair proteins such as $\mathrm{Ku}$ in response to DNA damage in tumor cells could associate anti-Ku with malignancies [25].

\section{CONCLUSIONS}

Because malignancy is one of the leading causes of mortality in patients with SSc, the identification of risk factors for the development of malignancy may have practical and prognostic implications [48]. Antinuclear antibodies may be considered potential diagnostic and predictive biomarkers of cancer (fig. 1). In particular, ne u 2\% pacjentów z SSc, jednak są szczególnie często wykrywane w surowicy chorych z zapaleniem mięśni w zespole nakładania (25\%) oraz innymi chorobami tkanki łącznej [40]. Obecność przeciwciał anty-PM-Scl stwierdzano już wcześniej u pacjentów z zapaleniem skórno-mięśniowym, zapaleniem wielomięśniowym i toczniem rumieniowatym układowym, u których rozpoznano nowotwór [41, 42]. Nowe doniesienia wskazują jednak na prawdopodobną zależność między tymi przeciwciałami a zwiększoną zapadalnością na nowotwory w przebiegu SSc. Ryzyko wystąpienia choroby nowotworowej oceniono na 3,9-krotnie wyższe u osób z przeciwciałami anty-PM-Scl niż u pacjentów z SSc bez przeciwciał tego typu [43].

\section{Przeciwciała anty-Ku}

Przeciwciała przeciw antygenowi Ku, który jest białkiem uczestniczącym w naprawie DNA, były związane głównie z zespołem nakładania się tocznia rumieniowatego układowego z twardziną układową [44]. Przeciwciała te można również wykryć u $2 \%$ pacjentów z SSc [45]. U pacjentów z tymi przeciwciałami najczęściej stwierdza się zapalenie mięśni oraz zapalenie stawów ze współistniejącą śródmiąższową chorobą płuc [46]. Wykazano ponadto, że u osób z przeciwciałami anty-Ku i twardziną układową występuje większe prawdopodobieństwo nowotworu niż u pacjentów bez tych przeciwciał $(27 \%$ w porównaniu z 8\%) [47]. Oszacowano, że u pacjentów z tymi przeciwciałami ogólne ryzyko rozwoju nowotworu ulega 4,6-krotnemu podwyższeniu. Do

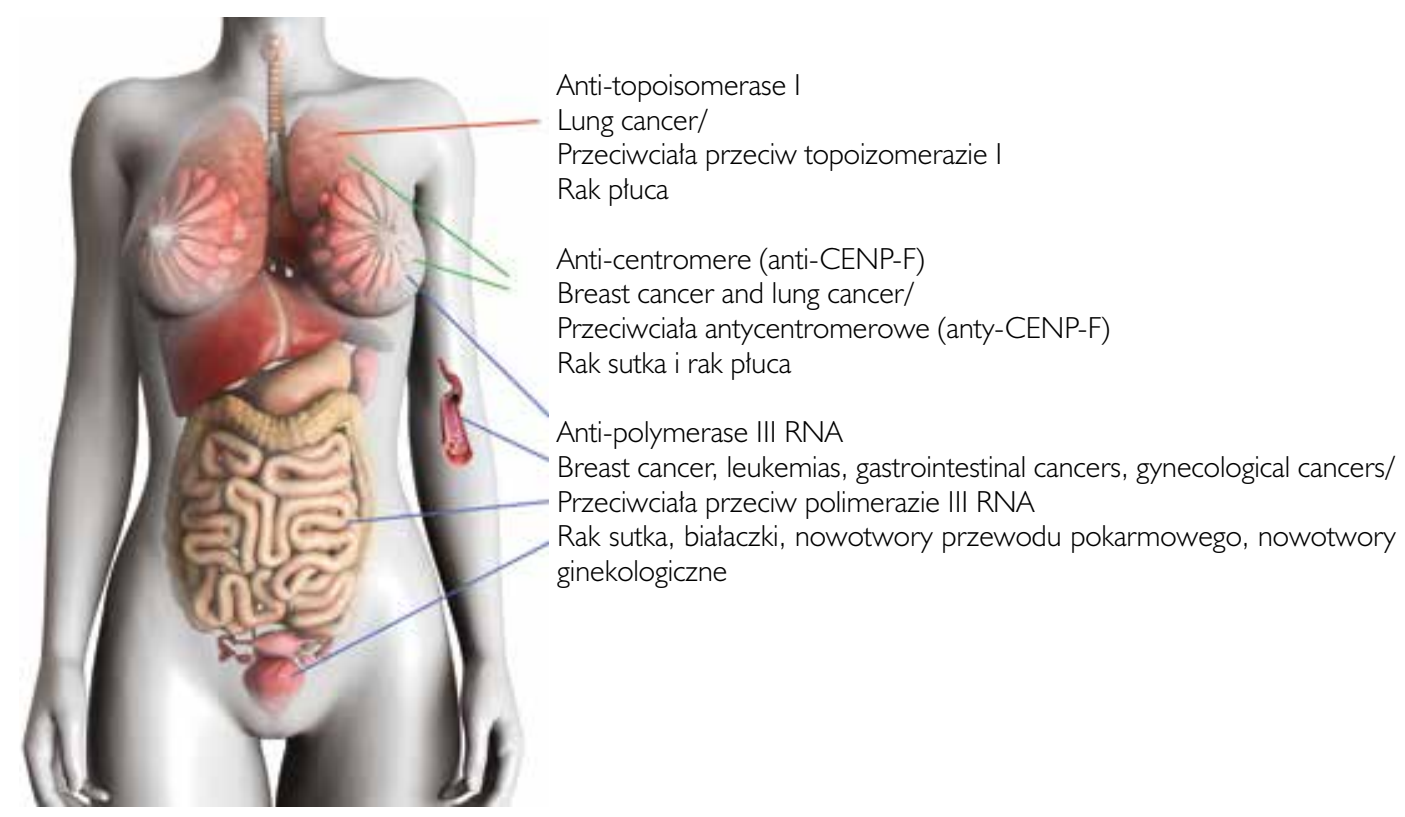

Figure I. Summary of current knowledge about the increased risk of diverse malignant diseases in patients with systemic sclerosis depending on the type of antinuclear antibodies

Rycina I. Podsumowanie aktualnego stanu wiedzy na temat zwiększonego ryzyka występowania różnych chorób nowotworowych u pacjentów z twardziną układową w zależności od typu przeciwciał przeciwjądrowych 
detecting either anti-RNAP III, anti-TOPO I, ACA, antiPM-Scl or anti-Ku antibodies might be useful in identifying patients with an increased risk of neoplasms and allows the implementation of effective cancer screening from the beginning of SSc diagnosis.

\section{CONFLICT OF INTEREST}

The authors declare no conflict of interest. najczęściej występujących nowotworów należały: czerniak, rak sutka oraz rak kolczystokomórkowy skóry [47]. Korelację między przeciwciałami anty-Ku i nowotworami można wyjaśnić wywoływaniem autoimmunizacji przez zmiany genetyczne antygenu Ku oraz mimikrą molekularną. Alternatywnie za zależność między przeciwciałami anty-Ku i nowotworami może odpowiadać nadekspresja białek naprawczych, takich jak Ku, w reakcji na uszkodzenie DNA w komórkach nowotworowych [25].

\section{WNIOSKI}

Nowotwory stanowią jedną z istotnych przyczyn śmiertelności pacjentów z SSc. Z tego względu identyfikacja czynników ryzyka rozwoju nowotworów może mieć istotne implikacje praktyczne i prognostyczne [48]. Przeciwciała przeciwjądrowe można uznać za potencjalne biomarkery diagnostyczne i predykcyjne występowania nowotworów (ryc. 1). Szczególnie przydatne z punktu widzenia identyfikacji pacjentów z grupy zwiększonego ryzyka rozwoju nowotworów oraz wdrożenia skutecznych badań przesiewowych w kierunku chorób nowotworowych jest wykrywanie przeciwciał anty-RNAP III, anty-TOPO I, ACA, anty-PM-Scl i anty-Ku.

\section{KONFLIKT INTERESÓW}

Autorzy nie zgłaszają konfliktu interesów.

\section{References \\ Piśmiennictwo}

1. Steen V.D.: Autoantibodies in systemic sclerosis. Semin Arthritis Rheum 2005, 35, 35-42.

2. Mehra S., Walker J., Patterson K. Fritzler M.J.: Autoantibodies in systemic sclerosis. Autoimmun Rev 2013, 12, 340-354.

3. Knobler R., Moinzadeh P., Hunzelmann N., Kreuter A., Cozzio A., Mouthon L., et al.: European Dermatology Forum S1-guideline on the diagnosis and treatment of sclerosing diseases of the skin, Part 1: localized scleroderma, systemic sclerosis and overlap syndromes. J Eur Acad Dermatol Venereol 2017, 31, 1401-1424.

4. Krasowska D., Rudnicka L., Dańczak-Pazdrowska A., Chodorowska G., Woźniacka A., Lis-Święty A., et al.: Systemic sclerosis - diagnostic and therapeutic recommendations of the Polish Dermatological Society. Part 1: diagnosis and monitoring. Dermatology Review/Przegląd Dermatologiczny 2017, 104, 483-498.

5. Vlagea A., Falagan S., Gutierrez-Gutierrez G., Moreno-Rubio J., Merino M., Zambrana F., et al.: Antinuclear antibodies and cancer: a literature review. Crit Rev Oncol Hematol 2018, 127, 42-49.

6. Moinzadeh P., Nihtyanova S.I., Howell K., Ong V.H., Denton C.P.: Impact of hallmark autoantibody reactivity on early diagnosis in scleroderma. Clin Rev Allergy Immunol 2012, 43, 249-255.

7. Imran A., Neelam F. Tariq M.: Incidence of circulating antinuclear antibodies in cancer patients. Indian J Med Sci 2003, 57, 113-116.

8. Szekanecz E., Andras C., Sandor Z., Antal-Szalmas P., Szanto J., Tamasi L., et al.: Malignancies and soluble tumor antigens in rheumatic diseases. Autoimmun Rev 2006, 6, 42-47.

9. Sargin G., Senturk T. Cildag S.: Systemic sclerosis and malignancy. Int J Rheum Dis 2018, 21, $1093-1097$.

10. Szekanecz Z., Szekanecz E., Bako G., Shoenfeld Y.: Malignancies in autoimmune rheumatic diseases - a mini-review. Gerontology 2011, 57, 3-10.

11. Abu-Shakra M., Guillemin F., Lee P.: Cancer in systemic sclerosis. Arthritis Rheum 1993, 36, $460-464$.

12. Olesen A.B., Svaerke C., Farkas D.K. Sorensen H.T.: Systemic sclerosis and the risk of cancer: a nationwide population-based cohort study. Br J Dermatol 2010, 163, 800-806. 
13. Szekanecz E., Szamosi S., Horvath A., Nemeth A., Juhasz B., Szanto J., et al.: Malignancies associated with systemic sclerosis. Autoimmun Rev 2012, 11, 852-855.

14. Kasifoglu T., Yasar Bilge S., Yildiz F., Ozen G., Pehlivan Y., Yilmaz N., et al.: Risk factors for malignancy in systemic sclerosis patients. Clin Rheumatol 2016, 35, 1529-1533.

15. Lu T.Y., Hill C.L., Pontifex E.K., Roberts-Thomson P.J.: Breast cancer and systemic sclerosis: a clinical description of 21 patients in a population-based cohort study. Rheumatol Int 2008, 28, 895-899.

16. Asten P., Barrett J. Symmons D.: Risk of developing certain malignancies is related to duration of immunosuppressive drug exposure in patients with rheumatic diseases. J Rheumatol 1999, 26, 1705-1714.

17. Shah A.A., Hummers L.K., Casciola-Rosen L., Visvanathan K., Rosen A., Wigley F.M.: Examination of autoantibody status and clinical features associated with cancer risk and cancer-associated scleroderma. Arthritis Rheumatol 2015, 67, 1053-1061.

18. Sobanski V., Dauchet L., Lefevre G., Lambert M., Morell-Dubois S., Sy T., et al.: Prevalence of anti-RNA polymerase III antibodies in systemic sclerosis: new data from a French cohort and a systematic review and meta-analysis. Arthritis Rheumatol 2014, 66, 407-417.

19. Denton C.P., Steen V.: Scleroderma renal crisis. [in:] Scleroderma: From Pathogenesis to Comprehensive Management. J. Varga, C.P. Denton, F.M. Wigley (eds.). Springer US Boston, MA, 2012, 361-371.

20. Airo P., Ceribelli A., Cavazzana I., Taraborelli M., Zingarelli S., Franceschini F.: Malignancies in Italian patients with systemic sclerosis positive for anti-RNA polymerase III antibodies. J Rheumatol 2011, 38, 1329-1334.

21. Moinzadeh P., Fonseca C., Hellmich M., Shah A.A., Chighizola C., Denton C.P., et al.: Association of anti-RNA polymerase III autoantibodies and cancer in scleroderma. Arthritis Res Ther 2014, 16, R53.

22. Saigusa R., Asano Y., Nakamura K., Miura S., Ichimura Y., Takahashi T., et al.: Association of anti-RNA polymerase III antibody and malignancy in Japanese patients with systemic sclerosis. J Dermatol 2015, 42, $524-527$.

23. Lazzaroni M.G., Cavazzana I., Colombo E., Dobrota R., Hernandez J., Hesselstrand R., et al.: Malignancies in patients with anti-RNA polymerase III antibodies and systemic sclerosis: analysis of the EULAR Scleroderma Trials and Research Cohort and Possible Recommendations for Screening. J Rheumatol 2017, 44, 639-647.

24. Shah A.A., Rosen A., Hummers L., Wigley F., Casciola-Rosen L.: Close temporal relationship between onset of cancer and scleroderma in patients with RNA polymerase I/III antibodies. Arthritis Rheum 2010, 62, 2787-2795.

25. Joseph C.G., Darrah E., Shah A.A., Skora A.D., Casciola-Rosen L.A., Wigley F.M., et al.: Association of the autoimmune disease scleroderma with an immunologic response to cancer. Science 2014, 343, 152-157.

26. Shah A.A., Casciola-Rosen L., Rosen A.: Review: cancer-induced autoimmunity in the rheumatic diseases. Arthritis Rheumatol 2015, 67, 317-326.

27. Teng M.W., Smyth M.J.: Cancer. Can cancer trigger autoimmunity? Science 2014, 343, 147-148.

28. Poormoghim H., Moghadam A.S., Moradi-Lakeh M., Jafarzadeh M., Asadifar B., Ghelman M., et al.: Systemic sclerosis: demographic, clinical and serological features in 100 Iranian patients. Rheumatol Int 2013, 33, 1943-1950.

29. Douvas A.S., Achten M., Tan E.M.: Identification of a nuclear protein (Scl-70) as a unique target of human antinuclear antibodies in scleroderma. J Biol Chem 1979, 254, 10514-10522.

30. Hanke K., Dahnrich C., Bruckner C.S., Huscher D., Becker M., Jansen A., et al.: Diagnostic value of anti-topoisomerase I antibodies in a large monocentric cohort. Arthritis Res Ther 2009, 11, R28.

31. Colaci M., Giuggioli D., Sebastiani M., Manfredi A., Vacchi C., Spagnolo P., et al.: Lung cancer in scleroderma: results from an Italian rheumatologic center and review of the literature. Autoimmun Rev 2013, 12, 374-379.

32. Onishi A., Sugiyama D., Kumagai S., Morinobu A.: Cancer incidence in systemic sclerosis: meta-analysis of population-based cohort studies. Arthritis Rheum 2013, 65, 1913-1921.

33. Hudson M., Mahler M., Pope J., You D., Tatibouet S., Steele R., et al.: Clinical correlates of CENP-A and CENP-B antibodies in a large cohort of patients with systemic sclerosis. J Rheumatol 2012, 39, 787-794.

34. Rattner J.B., Rees J., Whitehead C.M., Casiano C.A., Tan E.M., Humbel R.L., et al.: High frequency of neoplasia in patients with autoantibodies to centromere protein CENP-F. Clin Invest Med 1997, 20, 308-319.

35. Higuchi M., Horiuchi T., Ishibashi N., Yoshizawa S., Niho Y. Nagasawa K.: Anticentromere antibody as a risk factor for cancer in patients with systemic sclerosis. Clin Rheumatol 2000, 19, 123-126.

36. Launay D., Le Berre R., Hatron P.Y., Peyrat J.P., Hachulla E., Devulder B., et al.: Association between systemic sclerosis and breast cancer: eight new cases and review of the literature. Clin Rheumatol 2004, 23, 516-522.

37. Schilders G., van Dijk E., Raijmakers R., Pruijn G.J.: Cell and molecular biology of the exosome: how to make or break an RNA. Int Rev Cytol 2006, 251, 159-208.

38. Melo S.A., Sugimoto H., O'Connell J.T., Kato N., Villanueva A., Vidal A., et al.: Cancer exosomes perform cell-independent microRNA biogenesis and promote tumorigenesis. Cancer Cell 2014, 26, 707-721.

39. Azmi A.S., Bao B., Sarkar F.H.: Exosomes in cancer development, metastasis, and drug resistance: a comprehensive review. Cancer Metastasis Rev 2013, 32, 623-642.

40. Brouwer R., Hengstman G.J., Vree Egberts W., Ehrfeld H., Bozic B., Ghirardello A., et al.: Autoantibody profiles in the sera of European patients with myositis. Ann Rheum Dis 2001, 60, 116-123.

41. Marie I., Lahaxe L., Benveniste O., Delavigne K., Adoue D., Mouthon L., et al.: Long-term outcome of patients with polymyositis/dermatomyositis and anti-PM-Scl antibody. Br J Dermatol 2010, 162, 337-344.

42. Cabrera C.M., Fernandez-Grande E., Urra J.M.: Serological profile and clinical features of nucleolar antinuclear pattern in patients with systemic lupus erythematosus from southwestern Spain. Lupus 2016, 25, 980-987.

43. Bernal-Bello D., de Tena J.G., Guillen-Del Castillo A., Selva-O'Callaghan A., Callejas-Moraga E.L., Marin-Sanchez A.M., et al.: Novel risk factors related to cancer in scleroderma. Autoimmun Rev 2017, 16, 461-468.

44. Mimori T.: Clinical significance of anti-Ku autoantibodies: a serologic marker of overlap syndrome? Intern Med 2002, 41, 1096-1098.

45. Cavazzana I., Ceribelli A., Quinzanini M., Scarsi M., Airo P., Cattaneo R., et al.: Prevalence and clinical associations of anti$\mathrm{Ku}$ antibodies in systemic autoimmune diseases. Lupus 2008, 17, 727-732. 
46. Cavazzana I., Fredi M., Taraborelli M., Quinzanini M., Tincani A., Franceschini F.: A subset of systemic sclerosis but not of systemic lupus erythematosus is defined by isolated anti-Ku autoantibodies. Clin Exp Rheumatol 2013, 31, 118-121.

47. Hoa S., Hudson M., Troyanov Y., Proudman S., Walker J., Stevens W., et al.: Single-specificity anti-Ku antibodies in an international cohort of 2140 systemic sclerosis subjects: clinical associations. Medicine (Baltimore) 2016, 95, e4713.

48. Tyndall A.J., Bannert B., Vonk M., Airo P., Cozzi F., Carreira P.E., et al.: Causes and risk factors for death in systemic sclerosis: a study from the EULAR Scleroderma Trials and Research (EUSTAR) database. Ann Rheum Dis 2010, 69, 1809-1815.

49. Kuo C.F., Luo S.F., Yu K.H., Chou I.J., Tseng W.Y., Chang H.C., et al.: Cancer risk among patients with systemic sclerosis: a nationwide population study in Taiwan. Scand J Rheumatol 2012, 41, 44-49.

50. Roumm A.D., Medsger T.A. Jr.: Cancer and systemic sclerosis. An epidemiologic study. Arthritis Rheum 1985, 28, $1336-1340$.

51. Hashimoto A., Arinuma Y., Nagai T., Tanaka S., Matsui T., Tohma S., et al.: Incidence and the risk factor of malignancy in Japanese patients with systemic sclerosis. Intern Med 2012, 51, 1683-1688.

52. Derk C.T., Rasheed M., Artlett C.M., Jimenez S.A.: A cohort study of cancer incidence in systemic sclerosis. J Rheumatol 2006, 33, 1113-1116.

53. Hill C.L., Nguyen A.M., Roder D., Roberts-Thomson P.: Risk of cancer in patients with scleroderma: a population based cohort study. Ann Rheum Dis 2003, 62, 728-731.

Received: 17.05 .2018

Accepted: 10.09 .2018

Otrzymano: $17.05 .2018 \mathrm{r}$.

Zaakceptowano: 10.09 .2018 r.

How to cite this article

Stochmal A., Sar-Pomian M., Czuwara J., Rudnicka L.: Antinuclear antibodies in systemic sclerosis associated with increased risk of malignancy. Dermatol Rev/Przegl Dermatol 2018, 105, 604-612. DOI: https://doi.org/10.5114/dr.2018.79172. 